\title{
The Crystal Structure of $\mathrm{BaCa}\left(\mathrm{CO}_{3}\right)_{2}$ (barytocalcite)
}

\author{
B. Dickens and J. S. Bowen* \\ Institute for Materials Research, National Bureau of Standards, Washington, D.C. 20234
}

(February 3, 1971)

\begin{abstract}
The barytocalcite phase of $\mathrm{BaCa}\left(\mathrm{CO}_{3}\right)_{2}$ crystallizes in the monoclinic unit cell $a=8.092(1) \AA$. $b=5.2344(6) \AA, c=6.544(1) \AA, \beta=106.05(1)^{\circ}$ at $25^{\circ} \mathrm{C}$ with cell contents of $2\left[\mathrm{BaCa}\left(\mathrm{CO}_{3}\right)_{2} \mid\right.$. The structure previously reported by Alm is correct in its coarse details but has been redetermined here and refined to $R_{w}=0.028, R=0.023$ in space-group $\mathrm{P} 2{ }_{1} / \mathrm{m}$ using 1652 observed reflections. Corrections were made for absorption, isotropic extinction, and anomalous dispersion.

The structure of barytocalcite has an ... ABCABC ... stacking of cation layers and repeat every 3 layers. The calcite phase of $\mathrm{CaCO}_{3}$ has an $\mathrm{ABC}$ cation layer sequence and repeats every 6 layers. The orientations of the $\mathrm{CO}_{3}$ groups in barytocalcite are like the $\mathrm{CO}_{3}$ group orientation in the aragonite phase of $\mathrm{CaCO}_{3}$, and are rotated about $30^{\circ}$ from the $\mathrm{CO}_{3}$ group orientation in calcite. The cation layer sequence in aragonite is ... ABAB ... and the structure repeats every 2 layers.

The $\mathrm{Ca}$ ion in barytocalcite is coordinated to seven oxygens, including an edge of a $\mathrm{CO}_{3}$ group, with $\mathrm{Ca}$... . O distances in the range 2.305(2) $\AA$ to $2.518(2) \AA$. The $\mathrm{Ba}$ ion is coordinated to five edges and one apex of the $\mathrm{CO}_{3}$ groups with $\mathrm{Ba}$. . . O distances ranging from 2.729(3) $\AA$ to $3.140(2) \AA$. The distances of the $\mathrm{C}$ atoms in the $\mathrm{CO}_{3}$ groups from the planes of the $\mathrm{O}$ atoms are $0.025(5) \AA$ and $0.022(4) \AA$ for $\mathrm{C}(1)$ and $\mathrm{C}(2)$, respectively.
\end{abstract}

Key words: Aragonite; barium calcium carbonate; calcium carbonate; crystal structure; single crystal $\mathrm{x}$-ray diffraction.

\section{Introduction}

The crystal structure of the barytocalcite phase of $\mathrm{BaCa}\left(\mathrm{CO}_{3}\right)_{2}$ has been redetermined in our program of structural investigations [1] ${ }^{1}$ on calcium carbonates, calcium phosphates, associated hydrates, and related compounds. The structural features in these compounds have important applications in understanding possible epitaxy, syntaxy, and substitutional solid solution in biological minerals such as hydroxyapatite $\left(\mathrm{Ca}_{5}\left(\mathrm{PO}_{4}\right)_{3} \mathrm{OH}\right)$ and calcite, aragonite and vaterite, the three phase of anhydrous $\mathrm{CaCO}_{3}$.

From a consideration of the morphologies, $d$-spacings and possible space-groups of barytocalcite and calcite, Gossner and Mussgnug [2] gave a structure for barytocalcite which is a rearrangement of the calcite structure. They assumed the space-group to be $\mathrm{P} 2{ }_{1}$. Alm [3] used a relatively large $(0.3 \mathrm{~mm})$ single crystal of barytocalcite and unfiltered $\mathrm{Cu}$ radiation to collect photographic data from the $h 0 l, h 1 l, h k 0$ and $\bar{h} k h$ levels. He also assumed the space-group to be $\mathrm{P} 2_{1}$, rather than $\mathrm{P} 2_{1} / \mathrm{m}$, on steric considerations which are invaltd. The structure he gave for barytocalcite differs from that given by Gossner and Mussgnug in the orientations of the $\mathrm{CO}_{3}$ groups. However, Alm made no corrections for what must have been considerable absorption, gave no

*Research Associate of the American Dental Association at the National Bureau of Standards, Washington, D.C. 20234.

Figures in brackets indicate the literature references at the end of this paper. standard deviations on any parameters and used limited film data. The structure of barytocalcite was, therefore, poorly known by modern standards, and has been redetermined here.

\section{Data Collection and Structure Refinement}

The crystal used in the data collection is an approximate sphere, radius 0.094(3) $\mathrm{mm}$, ground from a crystal from mineral sample R13868 (from Cumberland, England) obtained from the National Museum of Natural History, Smithsonian Institution, W ashington, D.C., and supplied by J. S. White, Jr. It was mounted in our usual way [4].

formula (ideal): $\mathrm{BaCa}\left(\mathrm{CO}_{3}\right)_{2}$ (barytocalcite phase). cell: monoclinic

$a=8.092(1) \AA$ at $25^{\circ} \mathrm{C}$

$b=5.2344(6) \AA$

$c=6.544(1) \AA$

$\beta=106.05(1)^{\circ}$

volume $=266.4 \AA^{3}$

space-group $\mathrm{P} 2_{1} / \mathrm{m}$; cell contents $2\left[\mathrm{BaCa}\left(\mathrm{CO}_{3}\right)_{2}\right]$

reciprocal lattice extinctions, $0 k 0: k=2 n+1$

calculated density $3.72 \mathrm{~g} \cdot \mathrm{cm}^{-3}$; observed density $3.71 \mathrm{~g} \cdot \mathrm{cm}^{-3}[5]$.

In the determination of the unit cell and in the collection and processing of data, the general procedure 
in reference [4] was followed. In the present case, 3379 reflections were collected from the $\pm h+k+l$ and $\pm h-k+l$ quadrants and merged into a unique set of 1772 , of which 1652 are "observed" and 120 are "unobserved." The $R$ factor

$$
\sum_{h k l}\left|F_{h k l}^{i}-F_{h k l}^{j}\right| / \sum F_{h k l}^{i}
$$

with $i<j$ between pairs $F_{h k l}^{i}$ and $F_{h k l}^{j}$ of observed equivalent reflections $F_{h k l}$ was 0.018 calculated over 1189 pairs. $i$ and $j$ are the sequence numbers in the list of equivalent reflections. Absorption corrections for a sphere with $\mu=85.6 \mathrm{~cm}^{-1}$ were applied. The maximum and minimum transmission factors were 0.347 and 0.317 , respectively.

The $\theta-2 \theta$ scans were carried out on an automated Picker $^{2}$ diffractometer at $2^{\circ} / \mathrm{min}$ for $2 \theta$; backgrounds were counted for $20 \mathrm{~s}$ each. Because the least significant digit in all counts was dropped by the Picker hardware, standard deviations, $\sigma_{h k l}$, of the structure factors, $F_{h k l}$, were estimated from $\sigma_{h k l}=F_{h k l} / 5.7$ for $F_{h k l}<5.7 ; \sigma_{h k l}=1$ for $5.7<F_{h k l}<30$; and $\sigma_{h k l}=F_{h k l} / 30$ for $F_{h k l}>30$ where $F_{\max }$ on this arbitrary scale is 113 . The scattering factors used were those for the neutral atoms in reference 6 for the x-ray 67 refinements and those in references 7 and 8 for the extinction and anomalous dispersion refinements.

The quasi-normalized structure factor statistics on our barytocalcite data indicate that the structure is acentric, since $\left\langle|E|>=0.885,\left\langle E^{2}\right\rangle=1.00\right.$ (fixed), $<\left|E^{2}-1\right|>=0.709 ;$ the corresponding theoretical values are $0.886,1.000,0.736$ for the acentric case and $0.798,1.000,0.968$ for the centric case. $E$ is the quasinormalized structure factor [9]. The fraction of $E$ values greater than $1.0,2.0$ and 3.0 , respectively, was found to be $0.405,0.0027$ and 0.0000 ; the corresponding theoretical values are $0.368,0.0183,0.0001$ for the acentric case and $0.317,0.0455,0.0027$ for the centric case. The statistical procedure suggested an average temperature factor, $B$, of about $2.5 \AA^{2}$ and an exponent of 1.00 for $\sin \theta / \lambda$. Our experience has been that the quasi-normalized structure factor statistics are normally much closer to the theoretical values and the exponent of $\sin \theta / \lambda$ is closer to 2.00 than was calculated here for barytocalcite.

Because of the presence of the strongly scattering $\mathrm{Ba}$ ions, this indication that the space-group is the acentric $\mathrm{P} 2{ }_{1}$ was not considered to be reliable. The structure of barytocalcite was redetermined by us from a sharpened Patterson function calculated with $\left(E^{2}-1\right)$ coefficients and an $F_{0}$ Fourier electron density synthesis phased from the positions of the $\mathrm{Ba}$ and $\mathrm{Ca}$ ions. The $y$ coordinate of $\mathrm{Ba}$ was set equal to zero to define the origin along $b$. The structure was refined isotropically in space-group $\mathrm{P} 2_{1}$ to $R_{w}=0.65, R=0.057$ and then anisotropically in $\mathrm{P} 2{ }_{1}$ to $R_{w}=0.036, R=0.028$ using the x-ray 67 system of computing programs [10]. The least-squares refinements used the full matrix,

Certain commercial equipment, instruments, or materials are identified in this paper in order to adequately specify the experimental procedure. In no case does such identification imply recommendation or endorsement by the National Bureau of $S$ tandards, nor does it imply that the materials or equipment identified is necessarily the best available for the purpose. minimized $\Sigma w\left(\left|F_{0}\right|-\left|F_{c}\right|\right)^{2}$, and included those unobserved reflections for which $F_{h k l}$ calculated more than $2 \sigma\left(F_{h k l}\right)$.

The highest peak in an electron density difference synthesis calculated after anisotropic refinement was equivalent to about $1 / 3$ of an electron and was $0.49 \AA$ from $\mathrm{Ba}$. When the space-group is assumed to be $\mathrm{P} 2_{1}$ the largest correlation coefficients are 0.90 to 0.95 between (i) $x$ of $\mathrm{O}(1)$ and $x$ of $\mathrm{O}(2)$, (ii) $z$ of $\mathrm{O}(1)$ and $z$ of $\mathrm{O}(2)$, (iii) $x$ of $\mathrm{O}(4)$ and $x$ of $\mathrm{O}(5)$ and (iv) $z$ of $\mathrm{O}(4)$ and $z$ of $\mathrm{O}(5) ; 0.80$ to 0.90 between (i) $B_{11}$ of $\mathrm{O}(1)$ and $B_{11}$ of $\mathrm{O}(2)$, (ii) $B_{13}$ of $\mathrm{O}(4)$ and $B_{13}$ of $\mathrm{O}(5)$, and (iii) $B_{23}$ of $\mathrm{O}(4)$ and $B_{23}$ of $\mathrm{O}(5)$. There are 48 correlation coefficients greater than 0.50 .

The isotropic extinction parameter, $r$, where $F^{2}=F_{\text {unc }}^{2}\left(1+\beta r F_{\text {unc }}^{2}\right)$ and $F_{\text {unc }}$ is the structure factor uncorrected for extinction, was then refined together with the structural and scale parameters using the least-squares program RFINE written by L. W. Finger of the Carnegie Institution of Washington; these refinements included only the observed reflections. The resulting $R$ values were $R_{w}=0.027, R=0.022$. The structure obtained had essentially the symmetry $\mathrm{P} 2{ }_{1} / \mathrm{m}$; subsequent anisotropic refinement in $\mathrm{P} 2 / \mathrm{m}$ gave $R_{w}=0.036, R=0.028$ without extinction refinement and $R_{w}=0.028, R=0.025$ in refinements in which $r$ refined to $0.000100(4) \mathrm{cm}$. All unconstrained parameters were varied. Finally, three cycles of refinement including corrections for anomalous dispersion and extinction gave $R_{w}=0.028, R=0.023 ; r$ became $0.000100(5) \mathrm{cm}$. The largest change in the other parameters was an increase of $\sim 0.1 \AA^{2}$ in all $B_{\text {ii }}$ parameters of Ca. In the final cycle, the average shift/error was 0.02 , and the standard deviation of an observation of unit weight, $\left[\Sigma w\left(F_{0}-F_{c}\right)^{2} /(1652-56)\right]^{1 / 2}$, was 0.43 .

The final $R_{w}$ values for the centric and acentric cases are near the limit of the experimental data. The weighting scheme is arbitrary, though reasonable. Further, there are large correlation coefficients in the acentric refinement. From the first two considerations, the authors feel that the ratio test [11] on $\Sigma w\left(F_{0}-F_{c}\right)^{2}$, the numerator of the $R_{w}$ term, is not really applicable in this border-line case, even though it appears from this test that refinement in the acentric $\mathrm{P} 2_{1}$ is to be preferred at a confidence level greater than 99.5 percent. Because refinement in the centric space-group $\mathrm{P} 2_{1} / \mathrm{m}$ gives essentially the same result as refinement in $\mathrm{P} 2_{1}$ but has more restraints which remove the high correlation coefficients, the space-group of barytocalcite is assumed here to be $\mathrm{P} 2_{1} / \mathrm{m}$. This is consistent with the symmetry of $2 / \mathrm{m}$ in the observed crystalline forms of the mineral [12]. With refinement in $\mathrm{P} 2_{1} / \mathrm{m}$, the largest correlation coefficients were removed, and only six were greater than 0.50 . The four largest were about 0.60 and were between the scale factor and the extinction parameter, and between the scale factor and $B_{11}, B_{22}$, and $B_{33}$ of $\mathrm{Ba}$.

Because Sr has been reported [13] in the alstonite phase of $\mathrm{BaCa}\left(\mathrm{CO}_{3}\right)_{2}$, a refinement of barytocalcite in which the cation positions were considered to be occupied by $\mathrm{Sr}^{2+}$ in solid solution was carried out using Finger's least-squares program. The occupan- 
TABLE 1. Atomic parameters for barytocalcite $\mathrm{BaCa}\left(\mathrm{CO}_{3}\right)_{2}$

\begin{tabular}{|c|c|c|c|c|c|c|c|c|c|}
\hline Atoms & $x$ & $y$ & $z$ & $B_{11} *$ & $B_{22}$ & $B_{33}$ & $B_{12}$ & $B_{13}$ & $B_{23}$ \\
\hline $\mathrm{Ba}$ & $0.14740(3)$ & 0.25 & $0.28824(3)$ & $0.883(6)$ & $0.646(6)$ & $0.652(6)$ & & $0.399(4)$ & \\
\hline $\mathrm{Ca}$ & $.62320(8)$ & .25 & $.19855(9)$ & $.64(2)$ & $.50(2)$ & $.58(1)$ & & $.21(1)$ & \\
\hline C(1) & $.8972(5)$ & .75 & $.2483(5)$ & $.83(8)$ & $.65(8)$ & $.55(7)$ & & $.17(8)$ & \\
\hline $\mathrm{O}(1)$ & $1.0057(4)$ & .75 & $.1393(4)$ & $1.44(9)$ & $1.31(9)$ & $1.03(8)$ & & $.77(7)$ & \\
\hline$O(2)$ & $0.8457(3)$ & $.9620(4)$ & $.3089(3)$ & $1.45(6)$ & $0.85(6)$ & $1.25(6)$ & $0.50(5)$ & $.45(6)$ & $0.03(5)$ \\
\hline $\mathrm{C}(2)$ & $.6149(4)$ & .25 & $.7468(5)$ & $0.68(8)$ & $.74(8)$ & $0.61(7)$ & & $.27(6)$ & \\
\hline$O(3)$ & $.6383(4)$ & .25 & $.5644(4)$ & $2.4(1)$ & $1.9(1)$ & $.80(7)$ & & $.97(8)$ & \\
\hline $\mathrm{O}(4)$ & $.6066(2)$ & $.4604(4)$ & $.8474(3)$ & $1.29(6)$ & $0.61(5)$ & $1.00(6)$ & $.16(4)$ & $.52(4)$ & $-.04(4)$ \\
\hline
\end{tabular}

Figures in parentheses are standard errors in the last significant figure quoted, and were computed in the final cycle of full-matrix leastsquares refinements.

*Thermal parameters have the form $\exp \left[-1 / 4\left(a^{* 2} B_{11} h^{2}+b^{* 2} B_{22} k^{2}+c^{* 2} B_{33} l^{2}+2 a^{*} b^{*} B_{12} h k+2 a^{*} c^{*} B_{13} h l+2 b^{*} c^{*} B_{23} k l\right)\right]$.

cies, 1.003(13) and 1.004(4), for Ba and Ca respectively, suggest that there is no solid solution of $\mathrm{Sr}$ ions in this sample of barytocalcite.

The atomic parameters from the final extinction refinement in space-group $\mathrm{P} 2 / \mathrm{m}$ are given in table 1. The observed structure factors are given in table 2.

\section{Description of the Structure}

The structure of barytocalcite (fig. 1) consists of $\mathrm{Ba} \ldots \mathrm{CO}_{3}$ chains and $\mathrm{Ca} \ldots \mathrm{CO}_{3}$ chains, both parallel to [001], in which the cations are coordinated to an edge of one neighboring $\mathrm{CO}_{3}$ group in the chain, and to an apex of the other $\mathrm{CO}_{3}$ group. The $\mathrm{C}(2) \mathrm{O}_{3}$ group is in the $\mathrm{CaCO}_{3}$ chain with its plane parallel to (100). The $\mathrm{C}(1) \mathrm{O}_{3}$ group is in the $\mathrm{BaCO}_{3}$ chain, with its plane nearly parallel to (101), and is pushed out of the line of the chain because of the large ionic radius of the $\mathrm{Ba}$ ion. The chains lie in layers parallel to (210), a perfect cleavage in $\mathrm{BaCa}\left(\mathrm{CO}_{3}\right)_{2}$. The structure may also be considered to consist of layers of $\mathrm{CO}_{3}$ groups coordinated to layers of cations, and is related in this way to the calcite [14] phase of $\mathrm{CaCO}_{3}$, with (201) of barytocalcite corresponding to (001) of calcite.

\subsection{The Barium Ion Environment}

The Ba ion is coordinated (fig. 1, table 3 ) to 11 oxygen atoms with $\mathrm{Ba}$. . . O distances less than $3.2 \AA$, i.e., in the normal range. These oxygens consist of 5 edges of $\mathrm{CO}_{3}$ groups, $\mathrm{O}\left(2,2^{\mathrm{I}}\right), \mathrm{O}\left(1^{\mathrm{I}}, 2^{\mathrm{II}}\right), \mathrm{O}\left(1^{\mathrm{II}}, 2^{\mathrm{III}}\right), \mathrm{O}(3,4)$, $\mathrm{O}\left(3^{\mathrm{I}}, 4^{\mathrm{I}}\right)$ and one apex, $\mathrm{O}(1)$. The $\mathrm{Ba}$ ion is more extensively coordinated than it is in the witherite phase of $\mathrm{BaCO}_{3}$, where it has a coordination of 9 oxygens. The structure of witherite resembles that of the aragonite phase of $\mathrm{CaCO}_{3}$.

TABLE 3. Ba environment in barytocalcite, $\mathrm{BaCa}\left(\mathrm{CO}_{3}\right)_{2}$

\begin{tabular}{l|c}
\hline \hline \multicolumn{1}{|c}{ Atoms } & Distance, $\AA$ \\
\hline $\mathrm{Ba}, \mathrm{O}(1)$ & $2.729(3)$ \\
$\mathrm{Ba}, \mathrm{O}\left(4,4^{\prime}\right)$ & $2.833(2)$ \\
$\mathrm{Ba}, \mathrm{O}\left(2,2^{\prime}\right)$ & $2.847(2)$ \\
$\mathrm{Ba}, \mathrm{O}\left(2^{\mathrm{II}}, 2^{\text {III)}}\right)$ & $2.904(2)$ \\
$\mathrm{Ba}, \mathrm{O}\left(1^{1}, 1^{11}\right)$ & $2.914(1)$ \\
$\mathrm{Ba}, \mathrm{O}\left(3,3^{1}\right)$ & $3.140(2)$ \\
$\mathrm{Ba}, \mathrm{C}(1)$ & $3.152(3)$ \\
$\mathrm{Ba}, \mathrm{C}(2)$ & $3.294(2)$ \\
\hline
\end{tabular}

In all tables of interatomic distances and angles, the quantities in parentheses are standard errors in the last significant figure and were computed from the standard errors in the atomic positional parameters and in the cell parameters. They include contributions from the variance covariance matrix. The atom labels refer to atoms in figure 1.
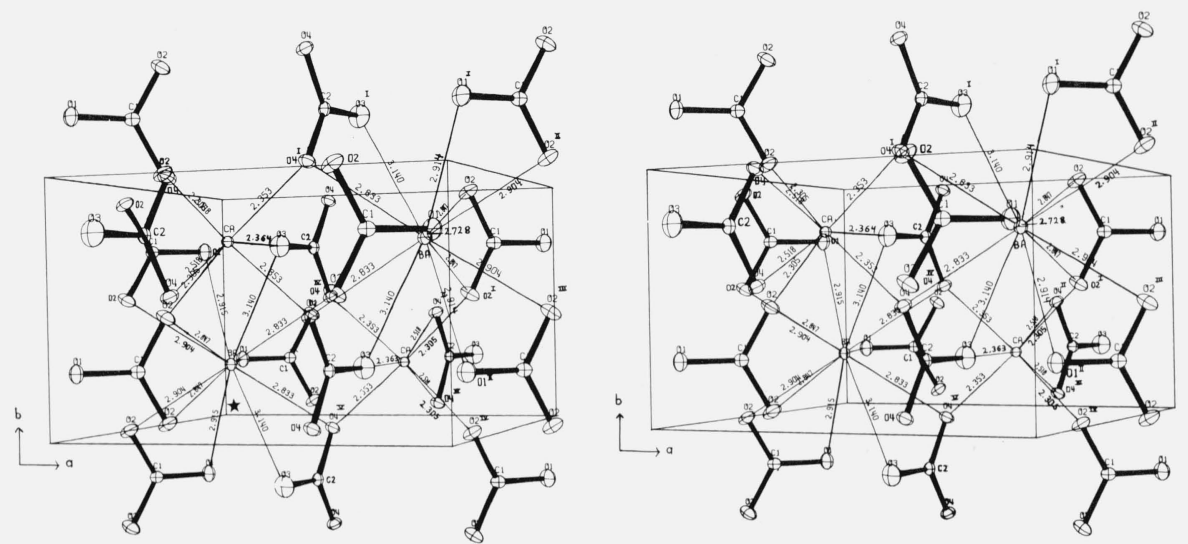

FigurE 1. The crystal structure of barytocalcite, $\mathrm{BaCa}\left(\mathrm{CO}_{3}\right)_{2}$, and the environments of the $\mathrm{Ba}$ and Ca ions.

The origin of the crystallographic coordinate system is marked by *. The labels refer to atoms in tables 3 and 4 . 
Table 2. Observed structure factors for barytocalcite, $\mathrm{BaCa}\left(\mathrm{CO}_{3}\right)_{2}$

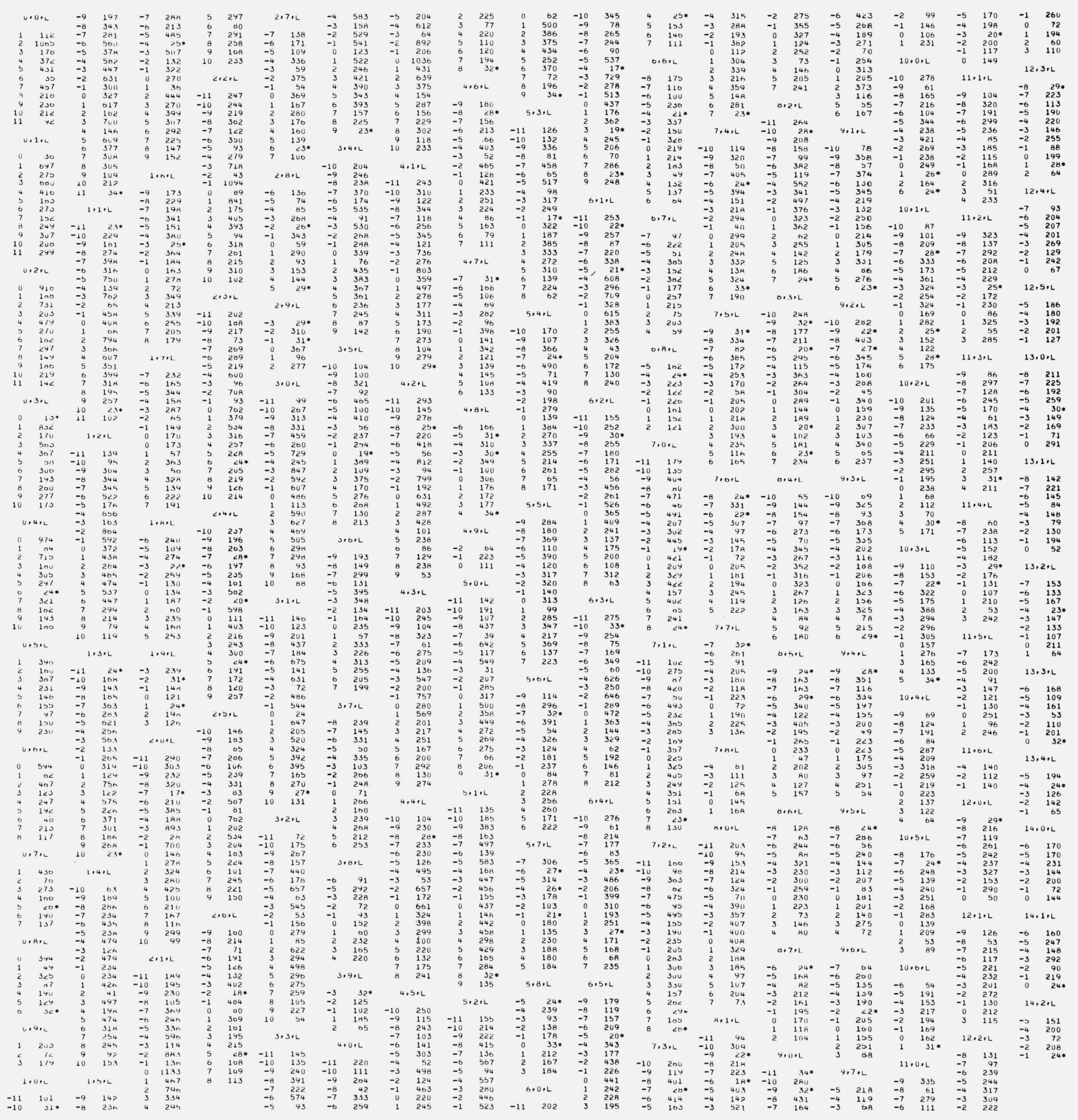

Columns are $\ell$, and $10 \mathrm{~F}_{0^{\circ}} \mathrm{F}_{\mathrm{o}^{\prime}}$ 's are on an absolute scale. "Unobserved" reflections are marked by *. 


\subsection{The Calcium Ion Environment}

The Ca ion is coordinated (fig. 1, table 4) to seven oxygen atoms, including one edge, $\mathrm{O}\left(4^{\mathrm{II}}, 4^{\mathrm{III}}\right)$, of a $\mathrm{CO}_{3}$ group, with $\mathrm{Ca}$. . O distances in the normal range. The five apex oxygen atoms lie in a square pyramid. The center of the coordinated edge of the $\mathrm{CO}_{3}$ group is near the remaining octahedral position. The coordination of $\mathrm{Ca}$ in barytocalcite is thus intermediate between the octahedral coordination of six $\mathrm{CO}_{3}$ apexes with no shared edges in the calcite phase of $\mathrm{CaCO}_{3}$ and the nine-fold coordination of three shared $\mathrm{CO}_{3}$ edges and three apexes in the aragonite phase of $\mathrm{CaCO}_{3}$.

TABLE 4. Ca environment in barytocalcite, $\mathrm{BaCa}\left(\mathrm{CO}_{3}\right)_{2}$

\begin{tabular}{c|c}
\hline \hline Atoms & Distance, $\AA$ \\
\hline $\mathrm{Ca}, \mathrm{O}\left(2^{\mathrm{I}}, 2^{\mathrm{IV}}\right)$ & $2.305(2)$ \\
$\mathrm{Ca}, \mathrm{O}\left(4^{\mathrm{I}}, 4^{\mathrm{V}}\right)$ & $2.353(2)$ \\
$\mathrm{Ca}, \mathrm{O}(3)^{\mathrm{N}}$ & $2.364(3)$ \\
$\mathrm{Ca}, \mathrm{O}\left(4^{\mathrm{II}}, 4^{\mathrm{II}}\right)$ & $2.518(2)$ \\
\hline
\end{tabular}

The atomic labels refer to atoms in figure 1.

\subsection{The Carbonate Groups and Their Environments}

There are two crystallographically different $\mathrm{CO}_{3}$ groups in the structure. One (table 5 , fig. 2 ) is in the $\mathrm{Ba} \ldots \mathrm{CO}_{3}$ chains and the other (table 5, fig. 2) is in the $\mathrm{Ca} \ldots \mathrm{CO}_{3}$ chains. The former, the $\mathrm{C}(1) \mathrm{CO}_{3}$ group, coordinates with all edges to $\mathrm{Ba}$ ions, and coordinates one apex, $\mathrm{O}(1)$, to another $\mathrm{Ba}$ ion. The two remaining apexes $\mathrm{O}\left(2,2^{1}\right)$ are coordinated to $\mathrm{Ca}$ ions.

The $\mathrm{C}(2) \mathrm{CO}_{3}$ group coordinates the edge containing the $\mathrm{O}\left(4,4^{\mathrm{I}}\right)$ atoms to $\mathrm{Ca}^{\mathrm{II}}$ and the remaining two edges,
TABLE 5. The carbonate anions and their environments in barytocalcite, $\mathrm{BaCa}\left(\mathrm{CO}_{3}\right)_{2}$

\begin{tabular}{|c|c|}
\hline $\mathrm{CO}_{3}$ groups & Distance or angle \\
\hline $\begin{array}{l}\mathrm{C}(1), \mathrm{O}(1) \\
\mathrm{C}(1), \mathrm{O}\left(2,2^{1}\right) \\
\mathrm{O}(1), \mathrm{O}(2) \\
\mathrm{O}(2), \mathrm{O}\left(2^{1}\right) \\
\mathrm{O}(1), \mathrm{C}(1), \mathrm{O}(2) \\
\mathrm{O}(2), \mathrm{C}(1), \mathrm{O}\left(2^{1}\right)\end{array}$ & $\begin{array}{c}1.275(4) \AA \\
1.286(2) \\
2.221(3) \\
2.220(4) \\
120.3(2)^{\circ} \\
119.3(3)\end{array}$ \\
\hline $\begin{array}{l}\mathrm{C}(2), \mathrm{O}(3) \\
\mathrm{C}(2), \mathrm{O}\left(4,4^{\mathrm{1}}\right) \\
\mathrm{O}(3), \mathrm{O}(4) \\
\mathrm{O}(4), \mathrm{O}\left(4^{1}\right) \\
\mathrm{O}(3), \mathrm{C}(2), \mathrm{O}(4) \\
\mathrm{O}(4), \mathrm{C}(2), \mathrm{O}\left(4^{1}\right)\end{array}$ & $\begin{array}{c}1.259(4) \AA \\
1.294(2) \\
2.229(3) \\
2.203(4) \\
121.6(1)^{\circ} \\
116.6(3)\end{array}$ \\
\hline $\mathrm{O}$ environments & Distance, $\AA$ \\
\hline $\begin{array}{l}\mathrm{O}(1), \mathrm{Ba} \\
\mathrm{O}(1),\left(\mathrm{Ba}^{1}, \mathrm{Ba}^{\mathrm{II}}\right)\end{array}$ & $\begin{array}{l}2.729(3) \\
2.915(1)\end{array}$ \\
\hline $\begin{array}{l}\mathrm{O}(2), \mathrm{Ca}^{I I I} \\
\mathrm{O}(2), \mathrm{Ba}^{I I I} \\
\mathrm{O}(2), \mathrm{Ba}^{I I}\end{array}$ & $\begin{array}{l}2.305(2) \\
2.847(2) \\
2.904(2)\end{array}$ \\
\hline $\begin{array}{l}\mathrm{O}(3), \mathrm{Ca}^{\mathrm{I}} \\
\mathrm{O}(3),\left(\mathrm{Ba}^{\mathrm{N}}, \mathrm{Ba}{ }^{1}\right)\end{array}$ & $\begin{array}{l}2.364(3) \\
3.140(2)\end{array}$ \\
\hline $\begin{array}{l}\mathrm{O}(4), \mathrm{Ca}^{\mathrm{III}} \\
\mathrm{O}(4), \mathrm{Ca}^{\mathrm{II}} \\
\mathrm{O}(4),\left(\mathrm{Ba}^{\mathrm{V}}\right)\end{array}$ & $\begin{array}{l}2.353(2) \\
2.518(2) \\
2.833(2)\end{array}$ \\
\hline
\end{tabular}

The atomic labels refer to atoms in figure 2.

$\mathrm{O}(3,4)$ and $\mathrm{O}\left(3,4^{\mathrm{I}}\right)$, to ions $\mathrm{Ba}^{\mathrm{V}}$ and $\mathrm{Ba}^{\mathrm{IV}}$, respectively. The average values of the $\mathrm{C}-\mathrm{O}$ bond distance in the $\mathrm{C}(1)$ and $\mathrm{C}(2) \mathrm{CO}_{3}$ groups, $1.283 \AA$ and $1.283 \AA$, respectively, compare well with the $\mathrm{C}-\mathrm{O}$ bond lengths ob-
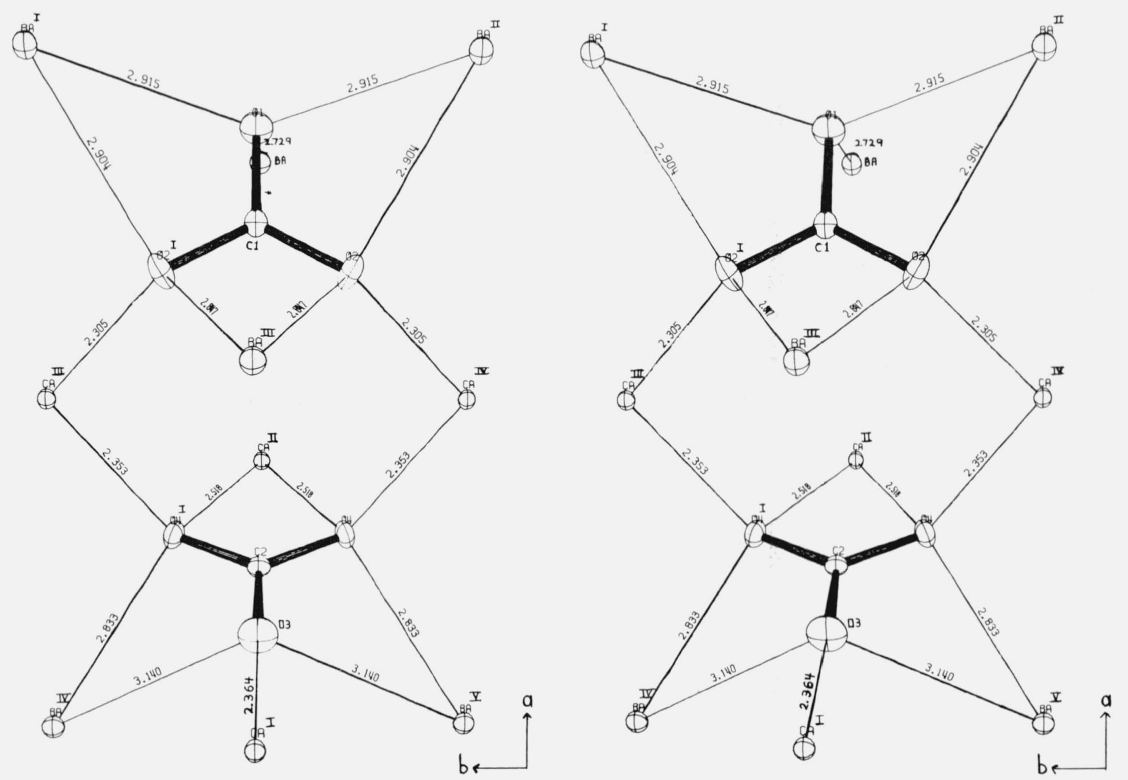

Figure 2. The $\mathrm{CO}_{3}$ environments in barytocalcite, $\mathrm{BaCa}\left(\mathrm{CO}_{3}\right)_{2}$. The labels refer to atoms in table 5 . 
served in the calcite $(1.283(2) \AA[14])$ and aragonite (1.288(2) and 1.283(1) A [4]) phases of $\mathrm{CaCO}_{3}$.

The two $\mathrm{CO}_{3}$ groups are nonplanar in barytocalcite. The displacements of $\mathrm{C}$ from the plane of the oxygen atoms are 0.025(5) $\AA$ for C(1) and 0.022(4) $\AA$ for $\mathrm{C}(2)$. Both displacements are toward the two central Ca ions $\mathrm{Ca}^{\mathrm{III}}$ and $\mathrm{Ca}^{\mathrm{IV}}$ in figure 2 , and probably arise from polarization of the $\mathrm{O}$ atoms by these Ca ions. Similarly distorted $\mathrm{CO}_{3}$ groups have been found in aragonite $[15,4]$ and $\mathrm{Ca}_{2} \mathrm{Na}_{2}\left(\mathrm{CO}_{3}\right)_{3}[1]$. (In calcite, the $\mathrm{CO}_{3}$ group point symmetry is constrained to 32 by the choice of $\mathrm{R} \overline{3} \mathrm{c}$ as the space-group.)

The different $\mathrm{C}-\mathrm{O}$ bond lengths in the $\mathrm{CO}_{3}$ groups (table 5) are consistent with the observed features in the structure. $\mathrm{O}(1)$ is bonded to three $\mathrm{Ba}$ ions. $\mathrm{O}(2)$ is bonded to two $\mathrm{Ba}$ ions and one $\mathrm{Ca}$ ion. Thus $\mathrm{O}(2)$ experiences stronger interaction with its cation neighbors, which is compatible with the $\mathrm{C}(1)-\mathrm{O}(2)$ distance being longer than $C(1)-O(1)$. Similarly, $O(4)$ is coordinated to two $\mathrm{Ca}$ ions and one $\mathrm{Ba}$ ion, whereas $\mathrm{O}(3)$ is coordinated to one $\mathrm{Ca}$ ion and two Ba ions. Thus, the $\mathrm{C}(2)-\mathrm{O}(4)$ bond distance is expected to be longer than the $\mathrm{C}(2)-\mathrm{O}(3)$ distance. Because the $\mathrm{O}\left(4,4^{\prime}\right)$ edge is coordinated to $\mathrm{Ca}$ whereas the $\mathrm{O}(3,4)$ and $\mathrm{O}\left(3,4^{\prime}\right)$ edges are coordinated to $\mathrm{Ba}$, the $\mathrm{O}(4), \mathrm{C}(2), \mathrm{O}\left(4^{\prime}\right)$ angle is expected to be less than $120^{\circ}$. Both these effects are realized.

Although $\mathrm{O}(2)$ and $\mathrm{O}(3)$ have similar environments, comparison of the lengths of the bonds $\mathrm{C}(1)-\mathrm{O}(2)$ and $\mathrm{C}(2)-\mathrm{O}(3)$ is not fruitful. Such a superficial comparison only applies when the oxygen atoms are competing in their bonding to the same central atom or when the other oxygens in the $\mathrm{CO}_{3}$ groups also have similar environments.

\section{Discussion}

Alm [3] showed that the structure given by Gossner and Mussgnug [2] is incorrect. The general features of the structure given by Alm for barytocalcite are correct to within $\sim 0.3 \AA$. The details given here are, however, far more precise. Gossner and Mussgnug and Alm gave the space-group of barytocalcite as $\mathrm{P} 2{ }_{1}$ in their limited analyses of the structure. Our more extensive analysis shows, however, that barytocalcite can be refined equally well, within the limits of the data, in the centrosymmetric space-group $\mathrm{P} 2{ }_{1} / \mathrm{m}$.

Barytocalcite is related to the calcite and aragonite phases of $\mathrm{CaCO}_{3}$. There are pseudo-hexagonal layers of cations parallel to (101) in the barytocalcite structure. If the difference between $\mathrm{Ca}$ and $\mathrm{Ba}$ is ignored, $\mathrm{a}$ pseudo-cell may be defined with $a^{\prime} \sim 8.7 \AA$ (along $[10 \overline{1}]), b^{\prime}=5.2 \mathrm{~A}$ (along [010]), $c^{\prime} \sim 9.2 \mathrm{~A}$ (along [101]) and $\beta^{\prime} \sim 95^{\circ}$. In this pseudo-cell, the cation layers repeat every third layer along $c^{\prime}$ as they do in calcite. The pseudo-cell of barytocalcite compares well with the orthohexagonal cell 8.641, 4.989, $17.062 \mathrm{~A}$ of calcite. The orientations of the $\mathrm{CO}_{3}$ groups in the two compounds calcite and barytocalcite differ by a rotation of $\sim 30^{\circ}$ (the $\mathrm{C}(2) \mathrm{O}_{3}$ group in barytocalcite further differs in that it makes an angle of $\sim 20^{\circ}$ with the (101) plane), and the cell repeat, $17.062 \AA$, perpendicular to the layers in calcite encompasses six cation layers whereas barytocalcite repeats every three cation layers. As regards the ... ABCABC ... sequence of cation layers, barytocalcite is like calcite. However, the rotation of the $\mathrm{CO}_{3}$ groups by $\sim 30^{\circ}$ relative to the $\mathrm{CO}_{3}$ positions in calcite relates barytocalcite to the aragonite phase of $\mathrm{CaCO}_{3}$. Thus the detailed coordinations of the $\mathrm{CO}_{3}$ groups are like those in aragonite, which also has $\mathrm{CO}_{3}$ groups rotated by $\sim 30^{\circ}$ from the $\mathrm{CO}_{3}$ positions in calcite, because all $\mathrm{CO}_{3}$ edges in both compounds are shared in coordination to neighboring cations and all apexes are further coordinated to cations. The coordinations of the cations in barytocalcite are however different from the coordination of $\mathrm{Ca}$ in aragonite, partly because in the former there are two differently sized cations.

W. E. Brown suggested the problem and gave helpful discussions; P. B. Kingsbury gave technical assistance. This investigation was supported in part by research grant DE-00572 to the American Dental Association from the National Institute of Dental Research and is part of the dental research program conducted by the National Bureau of Standards, in cooperation with the American Dental Association; the United States Army Medical Research and Development Command; the Dental Sciences Division of the School of Aerospace Medicine, USAF; the National Institute of Dental Research and the Veterans Administration.

\section{References}

[1] Dickens, B., Hyman, A., and Brown, W. E., The crystal structure of $\mathrm{Ca}_{2} \mathrm{Na}_{2}\left(\mathrm{CO}_{3}\right)_{3}$, (shortite), J. Res. Nat. Bur. Stand. (U.S.), 75A (Phys. and Chem.), No. 2, 129-135 (Mar--Apr. 1971).

[2] Gossner, B., and Mussgnug, F., Uber Alstonite und Milarit. Zbl. Mineral. Geol Palaont. A1930, 220 (1930); Beitrag zur Kenntnis des Baryto-calcites und seiner strukturellen Beiziehungen zu anderen Stoffen., Ibid. A1930, 321 (1930).

[3] Alm, K. F., The crystal structure of barytocalcite, $\mathrm{BaCa}\left(\mathrm{CO}_{3}\right)_{2}$, Arkiv for Mineralogi och Geologi 2, (1960) 399-410.

[4] Dickens, B., and Bowen, J. S., Refinement of the crystal structure of the aragonite phase of $\mathrm{CaCO}_{3}$, J. Res. Nat. Bur. Stand. 75A (Phys. and Chem.), No. 1, 27-32 (Jan.-Feb. 1971).

[5] Kreutz, S., Parallel growths of different substances, Min. Mag. 15, 232-237 (1909).

[6] International Tables for X-ray Crystallography, 3, (The Kynoch Press, Birmingham, England, 1962) p. 202.

[7] Cromer, D. T., and Mann, J. B., X-ray scattering factors computed from numerical Hartree-Fock wave functions, Acta Cryst. A24, 321-324 (1968).

[8] Cromer, D. T., Anomalous dispersion corrections computed from self-consistent field relativistic Dirac-Slater wave functions, Acta Cryst. 18, 17-23 (1965).

[9] Dickinson, C., Stewart, J. M., and Holden, J. R., A direct determination of the crystal structure of 2,3,4,6-tetranitroaniline, Acta Cryst. 21, 663-670 (1966).

[10] Stewart, J. M., editor, X-ray 67 program system for x-ray crystallography, Technical report 67-58, University of Maryland, College Park, Maryland 20742, December 1967.

[11] Hamilton, W. C., Significance tests on the crystallographic $R$ factor, Acta Cryst. 18,502-510 (1965).

[12] Palache, C., Berman, H., and Frondel, C., Dana's system of mineralogy, vol. II, 7th edition (John Wiley and Sons, Inc., New York, 1963) pp. 220 and 221. 
[13] Chang, L. L. Y., Subsolidus phase relations in the systems $\mathrm{BaCO}_{3}-\mathrm{SrCO}_{3}, \mathrm{SrCO}_{3}-\mathrm{CaCO}_{3}$ and $\mathrm{BaCO}_{3}-\mathrm{CaCO}_{3}$, J. Geol. 73, 346-368 (1965)

[14] Chessin, H., Hamilton, W. C., and Post, B., Position and thermal parameters of oxygen atoms in calcite, Acta Cryst. 18, 689-693 (1965).
[15] de Villiers, J. P. R., The crystal structures of aragonite, stronionite and witherite, Ph.D. Thesis, University of Illinois (1969).

(Paper 75A3-663) 